University of Michigan Law School

University of Michigan Law School Scholarship Repository

Law \& Economics Working Papers

3-14-2018

\title{
Texas Gulf Sulphur and the Genesis of Corporate Liability Under Rule 10b-5
}

\author{
Adam C. Pritchard \\ University of Michigan Law School, acplaw@umich.edu \\ Robert B. Thompson \\ Georgetown University Law Center, thompson@law.georgetown.edu
}

Follow this and additional works at: https://repository.law.umich.edu/law_econ_current

Part of the Law and Economics Commons

\section{Working Paper Citation}

Pritchard, Adam C. and Thompson, Robert B., "Texas Gulf Sulphur and the Genesis of Corporate Liability Under Rule 10b-5" (2018). Law \& Economics Working Papers. 154.

https://repository.law.umich.edu/law_econ_current/154

This Article is brought to you for free and open access by University of Michigan Law School Scholarship Repository. It has been accepted for inclusion in Law \& Economics Working Papers by an authorized administrator of University of Michigan Law School Scholarship Repository. For more information, please contact mlaw.repository@umich.edu. 


\title{
Texas Gulf Sulphur and the Genesis of Corporate Liability under Rule 10b-5
}

\author{
A.C. Pritchard \& Robert B. Thompson*
}

Draft 14 March 2018

Scholars have long recognized the seminal role played by SEC v. Texas Gulf Sulphur ${ }^{1}$ in transforming insider trading law. ${ }^{2}$ Less recognized is the opinion's foundational role in Rule 10b5's use to create a remedy against corporations for misstatements made by their officers (or others) even if the speaker had no evil motive. That less-discussed part of the case is our topic here, for it was an important early step in the growth of two key securities issues that took root during the $1960 \mathrm{~s}-$ the judicial implication of private rights of action under Rule $10 \mathrm{~b}-5$ and the expansion of obligations of corporate directors under "federal corporation law." ${ }^{3}$ Today, the issue of corporate liability lies at the heart of the ongoing debate over the social purpose and utility of securities fraud class actions. This Essay takes that question back to its historical roots in the 1960 s as the use of Rule $10 \mathrm{~b}-5$ was accelerating, focusing on the debate in Texas Gulf Sulphur among the judges of the Second Circuit, the "Mother Court" for securities law. ${ }^{4}$

Like its holding on insider trading, the Second Circuit's holding on corporate liability was deciding an issue that the Supreme Court had not yet come close to tackling. Each of the Texas Gulf Sulphur holdings, however, drew on the foundation provided by the expansive statutory

* Frances \& George Skestos Professor of Law, University of Michigan, and Peter P. Weidenbruch Jr. Professor of Business Law, Georgetown University, respectively. Pritchard acknowledges the generous financial support of the William W. Cook Endowment of the University of Michigan.

${ }^{1} 401$ F.2d 833 ( $2^{\text {nd }}$ Cir. 1968) (in banc).

${ }^{2}$ We have tackled that subject from a historical perspective in related work that focuses on how insider trading regulation shifted during the 1960s from a mechanistic approach under $\S 16(b)$ to a broad antifraud based remedy under Rule 10b-5. Securities Law in the Sixties: The Supreme Court, the Second Circuit, and the Triumph of Purpose over Text, 94 Notre Dame L. Rev. -- (forthcoming, 2018), available at: https://ssrn.com/abstract=3119969.

${ }^{3}$ See id. (developing the insider trading, private rights of action and federal corporation law as the three pillars of securities law that arose during the 60s).

${ }^{4}$ Blue Chip Stamps v. Manor Drug Stores, 421 U.S. 723, 762 (1975) (Blackmun, J. dissenting). 
interpretation used by the Supreme Court in two securities cases decided earlier in the decade, SEC v. Capital Gains Research Bureau and J.I. Case v. Borak. ${ }^{5}$ Capital Gains had endorsed a mode of statutory interpretation that focused on implementing the purpose underlying the securities laws, while J.I Case blessed the creation of novel causes of action by the judiciary to implement those purposes. The Second Circuit tackled the task of defining the elements of these newfound federal causes of action against the background of the common law. That embroiled the judges of the Second Circuit in a broader jurisprudential debate on the relative weight that should be afforded to text and purpose in statutory interpretation.

The question of the corporation's liability for private damages loomed large for the Second Circuit judges in Texas Gulf Sulphur, even though that question was not directly at issue in an SEC action for injunctive relief. But the judges recognized that the private damages issue under Rule $10 \mathrm{~b}-5$ was the 800 pound gorilla; a majority of the court's nine judges were inclined to find a way to limit the corporation's liability in the absence of wrongful intent. Two paths toward the goal of limiting corporate liability presented themselves. The first was based on the text of Rule $10 \mathrm{~b}-5^{6}$ and the statutory provision that authorizes it, $\S 10(\mathrm{~b})$ of the Exchange Act. ${ }^{7}$ The textual possibility was for the court to construe narrowly "in connection with the purchase or sale of any security," a requirement of both the rule and the statute. The alternative doctrinal direction that the Second Circuit could have pursued to narrow Texas Gulf Sulphur's potential liability borrowed from the common law of fraud: What was the requisite state of mind for the corporation making the misstatement?

\footnotetext{
5375 U.S. 180 (1963); 377 U.S. 426 (1964).

617 CFR 240.10b-5.

715 U.S.C $\S 78 \mathrm{j}(\mathrm{b})$.
} 
In the end, the Second Circuit majority in Texas Gulf Sulphur gave an expansive interpretation to each of these requirements, a surprising result given the tone of their discussions and the concerns raised about private causes of action. The simple explanation was the court's prudential retreat to address only the SEC's pursuit of an injunction. That resolution left for another day the looming issues arising from private actions for damages.

The court's holdings on both "in connection with" and state of mind shaped subsequent Supreme Court developments, but in divergent ways. The "in connection with" requirement, which got to the Supreme Court fairly quickly, produced a consistent, and indeed, even more expansive holding. In the following decade, however, the Court, with new personnel more committed to text than purpose, would reject negligence in favor of a more restrictive standard for state of mind.

We focus here on the role that text and purpose played in Texas Gulf Sulphur in delineating limits for corporate liability under Rule $10 b-5$ of the Exchange Act. We shed light on that debate over corporate liability by analyzing not only material available in the published opinions, but also the internal memos that the judges circulated among themselves prior to issuing the decision. ${ }^{8}$ In Part I, we take a deep dive into the deliberations among the Second Circuit judges on the question of corporate liability for material misstatements in Texas Gulf Sulphur. In Part II, we look at that decision's long-term implications for securities law, followed by a brief conclusion.

${ }^{8}$ We obtained copies of the memos from the Henry Friendly Collection at the Harvard Law School Library, hereinafter Friendly Collection. 


\section{Corporate Liability for Material Misstatements and Possible Limits}

The SEC complaint in the Texas Gulf Sulphur litigation presented two central claims. The first was against various individuals who had purchased company stock while having confidential inside information regarding an exceptionally rich ore find by the company. The second count against the corporation alleged misleading statements in company press releases issued to dampen rumors of that potentially enormous mineral find. The statements, viewed with the benefit of hindsight, understated the find in material ways. Even so, the press release did not seem motivated by a malevolent purpose. As Judge Henry Friendly put it in his concurring opinion

No one has asserted, or reasonably could assert, that the purpose for issuing a release was anything but good. TGS felt it had a responsibility to protect wouldbe buyers of its shares from what it regarded as exaggerated rumors first in the Canadian and then in the New York City press, and none of the individual defendants sought to profit from the decline in the price of TGS stock caused by the release. ${ }^{9}$

The press release showed poor judgment, not ill intent.

Although this case involved the SEC as a plaintiff seeking an injunction, Friendly was worried from the beginning about the difficulty of distinguishing government from private claims. ${ }^{10}$ He was wary of creating a potentially enormous new source of liability for corporations, a liability that would ultimately be borne by shareholders. After the case was submitted to the in banc panel, Friendly had written Harvard securities law professor Louis Loss, who he knew from the initial meetings leading to the American Law Institute's project to draft a comprehensive Federal Securities Code on which Friendly served as an adviser. The judge

${ }^{9}$ Texas Gulf Sulphur, 401 F.2d at 866.

${ }^{10}$ The district court in Texas Gulf Sulphur had noted that 49 private actions under Rule 10b-5 were pending. See 258 F. Supp., 262, 267, n.1. A private suit based on the same facts eventually reached the Tenth Circuit. See Mitchell v. Texas Gulf Sulphur Co., 446 F.2d 90, 103 (10th Cir.), cert. denied, 404 U.S. 1004 (1971). 
requested the relevant pages from Loss's forthcoming revision of his treatise "dealing with the remedial aspects of Rule $10 \mathrm{~b}-5$ as applied to private litigation, since I do not think we could deal intelligently with the instant case without considering its effect in that field."11 Friendly had already circulated a memo to his colleagues declaring that the corporation's liability for its press release was

the most important issue in the case. If there were any way to limit the holding to injunctive relief or even to actions brought by the SEC, the dangers inherent in the opinion of the panel majority would be anything like so great ... the financial consequences of holding corporation liable for innocent errors or omissions in press releases, all judged on a basis of hindsight, are incalculable. We kid ourselves when we talk of liability of 'the corporation'; the rule announced by the majority would cause thousands of innocent investors like ourselves, who buy stocks and put them away, to be mulcted for the benefit of tapewatchers and more particularly, of Pomerantz \& Co. ${ }^{12}$

The question of insider trading on the potential mineral find was the headline grabber, but Friendly recognized the substantially greater economic significance of the corporate liability issue.

The memos among the judges reveal that most of Friendly's colleagues shared his concern about corporations' liability for damages. As we discuss below, Kaufman and Anderson responded with sympathetic memos and joined in Friendly's concurrence in the published decision making this point. Feinberg's memo expressed similar worry, although he did not end up joining in Friendly's concurrence. The two dissenters to the decision, Moore and Lumbard, favored narrowing the corporation's liability. ${ }^{13}$

${ }^{11}$ Letter from Henry J. Friendly to Louis Loss (5/27/1968), Henry Friendly Collection, Box 135, Folder 5, Harvard Law School Library.

${ }_{12}$ Memo of HJF, SEC v. Texas Gulf Sulphur Co. (5/8/1968), Henry Friendly Collection, Box 135, Folder 5, Harvard Law School Library. Pomerantz is the name of a leading plaintiff's side firm of the era, one that is still active today. See http://pomerantzlawfirm.com/firm-history-1/.

${ }^{13}$ Friendly in a memo to his judicial colleagues on the Gerstle case characterized his concurring opinion in Texas Gulf Sulphur on this point was one that "commanded a majority of the court that something more than mere negligence was needed to create liability for money damages." Memo of HJF, 
As the debate unfolded in response to Friendly's memo, the judges considered two ways to rein in the possibility of large corporate damages for misstatements: 1) reading the "in connection with a purchase of sale" requirement narrowly, when the alleged wrongdoer had neither purchased nor sold; or 2) requiring scienter on the part of the corporation, the mental state required for an actor to held liable for damages for fraud. In the end, the judges in the majority limited their holding to injunction claims brought by the SEC, which was, after all, the issue before them. In that context, the majority provided an expansive reading of Rule $10 \mathrm{~b}-5$ which rested on its understanding of the purpose of the Exchange Act.

\section{A. In Connection With}

How broadly does the phrase "in connection with the purchase or sale of any security" sweep? It surely encompasses individuals and entities who make material misrepresentations while buying or selling securities. Texas Gulf Sulphur, however, was doing neither at the time it issued its ill-advised press release. If the company had been buying back shares at the time of its pessimistic press release (or more commonly, selling shares while making unduly optimistic statements), liability would have been straightforward, even under the common law of deceit. Indeed, a CEO purchasing shares while badmouthing the company's prospects was the impetus for the SEC's adoption of Rule 10b-5 back in $1942 .{ }^{14}$ But should liability extend to a corporation that was neither buying nor selling its own securities? The text offers little guidance, although the choice of "in connection with" rather than "in" suggests that Congress intended something broader than just privity. How close does the requisite "connection" to a securities transaction need to be?

Gerstle v. Gamble-Skogmo, at 4 (2/20/73), Henry Friendly Collection, Box 65, Folder 1, Harvard Law School Library.

${ }^{14}$ Conference on Codification of the Federal Securities Laws, 22 Bus. LAW. 793, 922 (1967) (comment by Milton Freeman, Attorney and Assistant Solicitor, SEC, 1934-46). 
The district court had concluded that the corporation's benign intentions-and the fact that it was not trading in its own securities-defeated the element that its misrepresentations be "in connection with the purchase or sale of any security." The lower court had held that "the issuance of a false and misleading press release may constitute a violation of Section 10(b) and Rule $10 \mathrm{~b}-5$ if its purpose is to affect the market price of the company's stock to the advantage of the company or its insiders." ${ }^{15}$ The district court's standard is reminiscent of the situation that gave rise to Rule $10 \mathrm{~b}-5$ 's adoption; the only twist in the standard is extending liability to the corporation as well as the officer who was manipulating the share price for his own benefit. But both circumstances were absent on the facts presented in Texas Gulf Sulphur.

The Second Circuit majority rejected the narrow construction of "in connection with" adopted by the district court, instead adopting a "reasonably calculated to influence the investing public" standard. ${ }^{16}$ The majority's rationale? "[T]he court below used a standard that does not reflect the congressional purpose that prompted the passage of the Securities Exchange Act of 1934." ${ }^{17}$ Purpose, not text, was the relevant standard, according to the majority, rolling out a quote from Judge Learned Hand in support of that position:

the purpose of a statutory provision is the best test of the meanings of the words chosen. We are to put ourselves so far as we can in the position of the legislature that uttered them, and decide whether or not it declare that the situation that has arisen is within what it wishes to cover. Indeed, at time the purpose may be so manifest as to override even the explicit words used. ${ }^{18}$

\footnotetext{
${ }^{15}$ SEC v. Texas Gulf Sulphur Co., 258 F.Supp. 262, 293 (SDNY 1966) (citing Freed v. Szabo Food Serv., Inc., CCH FED. SEC.L. REP. P91317 (N.D.III. 1964)).

${ }^{16}$ Texas Gulf Sulphur, 401 F.2d at 862 ("we hold that Rule 10b-5 is violated whenever assertions are made, as here, in a manner reasonably calculated to influence the investing public, e.g., by means of the financial media, if such assertions are false or misleading or are so incomplete as to mislead irrespective of whether the issuance of the release was motivated by corporate officials for ulterior purposes.") (citation omitted).

${ }^{17}$ Texas Gulf Sulphur, 401 F.2d at 858.

${ }^{18}$ Texas Gulf Sulphur, 401 F.2d at 861 (quoting Cawley v. United States, 272 F.2d 443, 445 (2 Cir.
} 1959) (L. Hand, J.). 
The purposes of the Exchange Act, according to the majority "were to promote public securities markets and to protect the investing public from suffering inequities in trading, including, specifically, inequities that follow from trading that has been stimulated by the publication of false or misleading corporate information releases." ${ }^{19}$ This finding of Congress's purpose was supported by legislative history proclaiming the virtues of corporate transparency. ${ }^{20}$

The majority took the additional step of citing other provisions of the securities laws with narrower prerequisites as "demonstrat[ing] that when Congress intended that there be a participation in a securities transaction as a prerequisite of a violation, it knew how to make that intention clear." ${ }^{21}$ (Of course, those provisions explicitly created private causes of action, in contrast to the judicially discovered cause of action under $\S 10(b)$.$) In the absence of clear$ language limiting the scope of $\S 10(b)$, the majority was willing to read the "in connection with" requirement as broadly as its reading of legislative purpose. The "obvious purposes of the Act to protect the investing public and to secure fair dealing in the securities markets would be seriously undermined" by a requirement that the defendants "engage[] in related securities transactions or otherwise act[] with wrongful motives."22 Stated at that level of abstraction, statutory purpose could invoked to support virtually any measure against fraud. There was no limiting principle.

The court majority did offer an evidentiary justification for its broad construction:

"Absent a securities transaction by an insider it is almost impossible to prove that a wrongful

\footnotetext{
${ }^{19}$ Texas Gulf Sulphur, 401 F.2d at 858.

${ }^{20}$ Texas Gulf Sulphur, 401 F.2d at 858-859 (citing H.R. Rep. No. $1383,73^{\text {rd }}$ Cong., $2^{\text {nd }}$ Sess. 11 (1934) and S.Rep. N. 792, $73^{\text {rd }}$ Cong. 2d Sess. 18 (1934).

${ }^{21}$ Texas Gulf Sulphur, 401 F.2d at 860 (citing $\S \S 12[a](2)$ and 17(a) of the Securities Act of 1933, 15 U.S.C. $\S 771(2)$ and $\S 777 q(a)$ and $\S 15$ of the Exchange Act, 15 U.S.C. § 78o(c)(1)).

${ }^{22}$ Texas Gulf Sulphur, 401 F.2d at 860.
} 
purpose motivated the issuance of the misleading statement." ${ }^{23}$ Adding a requirement of wrongful purpose to the "in connection with" requirement would make the anti-fraud prohibition underinclusive, in the majority's view. The absence of a securities transaction "does not negate the possibility of a wrongful purpose; perhaps the market did not react to the misleading statement as much as was anticipated or perhaps the wrongful purpose was something other than the desire to buy at a low price or sell at a high price." ${ }^{24}$ The first possibility seems somewhat fanciful-an attempt at fraud that fell short of the mark? The latter suggestion is at least speculative. More candidly, the court argued "that the investing public may be injured as much by one's misleading statement containing inaccuracies caused by negligence as by a misleading statement published intentionally to further a wrongful purpose." ${ }^{25}$ Once again, the majority fell back on what it viewed as the purpose of the statute-the protection of investors. The statutory text was, at most, a secondary consideration.

The majority's broad conclusion with respect to the "in connection with" argument got little pushback from the judges on the Second Circuit who had concerns about opening the door for corporate liability. Only two judges of the in banc court (the predictably conservative Moore and Lumbard) agreed with the district court's holding requiring a wrongful purpose. ${ }^{26}$ Moore argued that the majority's interpretation "indicates that Congress intended a revolutionary change in the whole thrust of the securities laws. That is too slim a basis to support a judicial excursion over such uncharted seas." ${ }^{27}$ Moore's characterization of the majority's holding

\footnotetext{
${ }^{23}$ Texas Gulf Sulphur, 401 F.2d at 860.

${ }^{24}$ Texas Gulf Sulphur, 401 F.2d at 860.

25 Texas Gulf Sulphur, 401 F.2d at 860.

${ }^{26}$ Texas Gulf Sulphur, 401 F.2d at 869, 881-889 (Moore, J., dissenting, joined by Lumbard, J.).

27 Texas Gulf Sulphur, 401 F.2d at 885.
} 
effecting a "revolutionary change" in securities regulation certainly proved prescient, but it

garnered little traction with his fellow judges.

Even the judges who were wary of expanding corporate liability were unwilling to sign

on to the restrictive interpretation of "in connection with." Friendly, for example, was alarmed

by the specter of corporate liability raised by the majority's holding.

It is inconceivable that Congress meant that the SEC's rule-making power under $\S 10$ (b) should enable it to impose on press releases and other company statements not made in the sale of a security a liability broader and unaccompanied by the procedural safeguards of $\S 12$ of the Securities Act or $\S$ 18 of the Exchange Act. Yet the combination of the majority's broad reading of 'In connection with' and its holding that Rule 10-b-5 encompasses negligent misrepresentation produces exactly that result. The consequences would be most serious. Either innocent stockholders will be damaged, as I have indicated, or companies will clam up ... ${ }^{28}$

Friendly at "first thought that the way of out of this dilemma was to agree with [Moore's]

limited reading of 'in connection with."'29 But he was dissuaded by issues raised in a case argued the same week as Texas Gulf Sulphur, Great American, ${ }^{30}$ as well as Louis Loss's position on the issue. $^{31}$

In his memo in the Texas Gulf Sulphur case, Irving Kaufman urged that "The 1934 Act and the rules adopted pursuant thereto contain broad remedial provisions that should be liberally construed; I fear that [Moore]'s limited reading would effectively insulate many

${ }^{28}$ Memo of HJF, SEC v. Texas Gulf Sulphur Co. (5/8/1968), Henry Friendly Collection, Box 135, Folder 5, Harvard Law School Library.

${ }^{29}$ Memo of HJF, SEC v. Texas Gulf Sulphur Co. (5/8/1968), Henry Friendly Collection, Box 135, Folder 5, Harvard Law School Library.

${ }^{30}$ SEC v. Great American Indus., Inc., 407 F.2d 453 (2 $2^{\text {nd }}$ Cir. 1968).

${ }^{31}$ Memo of HJF, SEC v. Texas Gulf Sulphur Co. (5/8/1968), Henry Friendly Collection, Box 135, Folder 5, Harvard Law School Library ("If this would be the last case to raise the issue [of "in connection with"], I would [agree with Moore]. But it won't be, as witness Great American. True we could distinguish that cases on that that GAl was constantly issuing stock, but this seems unsatisfactory and Professor Loss, who objects to an unlimited expansion of Rule 10-b-5, thinks the rule may be applied 'when a company publishes a prospectus or financial statement with the clear intention of conducting open-market purchases.' P. 1769."). 
predatory practices from commission purview." ${ }^{32}$ A new theme emerges here: judicial support

for limiting private lawsuits, but not if the limitation also constrained the SEC's authority. ${ }^{33}$ This

differential private/public treatment would be a recurring issue in the Supreme Court's

securities jurisprudence in subsequent years. ${ }^{34}$

Judge Willard Feinberg, like Friendly, viewed the press release as "the most important

issue in the case." Notwithstanding his concerns over corporate liability, Feinberg's take on the

"in connection with" issue is typical of his colleagues in Texas Gulf Sulphur.

imposing civil liability on the corporation because of this and no more, as [Henry Friendly] and [Irving Kaufman] have pointed out, could have disastrous results. In addition to inhibiting the flow of corporate information, private damage suits could bankrupt corporations, with the big losers including the very shareholders the rule is supposed to protect. Therefore, it does seem necessary to limit potential liability in a conceptually defensible way. However, narrowing the definition of "in connection with" is not wise. It will insulate intentionally misleading statements which are intended to affect stock prices; such deception should be covered by Rule 10b-5. The remedial intent of Congress can be better served by continuing to interpret "in connection with" broadly, but limiting the application of the Rule by other means. ${ }^{35}$

The "in connection with" requirement offered a textual basis for limiting corporate liability, but the language chosen by Congress hardly compelled a restrictive reading. More relevant for an intermediate appellate court, a narrow construction of the language would seem to fly in the

32 Memo of IRK, SEC v. Texas Gulf Sulphur Co. (5/14/1968), Henry Friendly Collection, Box 135, Folder 5, Harvard Law School Library.

${ }^{33}$ See also Memo of WF, SEC v. Texas Gulf Sulphur Co. (5/28/1968), Henry Friendly Collection, Box 135, Folder 5, Harvard Law School Library ("The justification for making ... a distinction [between injunctive relief and damages] here is even stronger, where the plaintiff is the Commission representing the public.") (citing SEC v. Capital Gains Research Bureau, Inc., 375 U.S. 180, 193 (1963) for the proposition "that ' $[i] t$ is not necessary in a suit for equitable or prophylactic relief to establish all the elements required in a suit for monetary damages."').

${ }^{34}$ See text at infra notes - .

${ }^{35}$ Memo of WF, SEC v. Texas Gulf Sulphur Co. (5/28/1968), Henry Friendly Collection, Box 135, Folder 5, Harvard Law School Library. See also Memo of JJS, SEC v. Texas Gulf Sulphur Co. (6/3/1968), Henry Friendly Collection, Box 135, Folder 5, Harvard Law School Library (Press release "was 'in connection with' purchase and sale of securities because of its intended and inevitable market effect.). 
face of the Supreme Court's instruction in Capital Gains that "securities legislation enacted for the purpose of avoiding frauds" was to be construed "not technically and restrictively, but flexibly to effectuate its remedial purposes." ${ }^{\prime 36}$ That instruction from above - issued in a case reversing a narrow reading of the securities laws by the Second Circuit-lurked in the background in Texas Gulf Sulphur, as it did in other expansive Second Circuit securities cases in the 1960 s.

\section{B. State of Mind}

Friendly pointed the way toward a means other than "in connection with" to limit the reach of Rule 10b-5. In Friendly's memo in the Great American case written just a day after his Texas Gulf Sulphur memo, he commented “Once we decide that 'in connection with' is not a useful method for bringing some limits on Rule 10-b-5 but that the way to do this is to impose some kind of guilty action requirement, this case is not a hard one. ${ }^{137}$ Here Friendly sees what would become the preferred method to limit $10 \mathrm{~b}-5$ by both the Supreme Court (Ernst \& Ernst, discussed below) and the Congress (Private Securities Litigation Reform Act). ${ }^{38}$

The issue of the requisite state of mind for a violation of Rule $10 \mathrm{~b}-5$ was still very much in play circa 1968. Neither Rule $10 b-5$, nor its underlying statute, $\S 10(b)$, explicitly set forth a required state of mind for violations. The possibilities ranged from strict liability, to negligence, to recklessness, to knowledge, or specific intent to harm. The common law of fraud rejected strict liability, perhaps included negligence as a species of equitable fraud, and generally accepted the last three possibilities in suits for damages. The question of state of mind was

${ }^{36}$ Capital Gains, 375 U.S. at 195 (citations and quotations omitted).

${ }^{37}$ Memo of HJF, SEC v. Great American Industries (5/9/1968), at 3, Henry Friendly Collection, Box 135, Folder 6, Harvard Law School Library.

${ }^{38}$ Pub. L. No. 104-67, 109 Stat. 737 (1995). 
further complicated by the fact that corporations do not have minds: they are fictional legal entities. Whose intentions would count?

The majority's arguments relating to "in connection with" overlap with its arguments relating to state of mind. ${ }^{39}$ The Second Circuit strongly sided with the SEC, rejecting the effort to "handicap unreasonably the Commission in its work." ${ }^{40}$ The court cited Capital Gains for the proposition that "[i]n an enforcement proceeding for equitable or prophylactic relief, the common law standard of deceptive conduct has been modified in the interests of broader protection for the investing public so that negligent insider conduct has become unlawful." ${ }^{41}$ The majority opted for the negligence standard, as "comport[ing] with the administrative and legislative purposes underlying the Rule" that would "promote[] the deterrence objective of the Rule." ${ }^{42}$ The only concession to concerns about corporate liability was to limit the negligence holding to injunctive actions brought by the SEC. ${ }^{43}$ Even there, however, the majority placed the burden on the defendant to establish its due diligence. ${ }^{44}$ Private suits for damages would wait for another day. ${ }^{45}$

\footnotetext{
${ }^{39}$ Taken to its logical conclusion, the majority's argument for rejecting wrongful purpose would
} require a strict liability standard, an argument that Justice Powell would gently mock the SEC for making in support of a negligence standard in Ernst \& Ernst v. Hochfelder, 425 U.S. 185, 198 (1976) ("The logic of this effect-oriented approach would impose liability for wholly faultless conduct where such conduct results in harm to investors, a result the Commission would be unlikely to support.").

${ }^{40}$ Texas Gulf Sulphur, 401 F.2d at 861.

${ }^{41}$ Texas Gulf Sulphur, 401 F.2d at 854-855.

${ }^{42}$ Texas Gulf Sulphur, 401 F.2d at 855.

${ }^{43}$ Texas Gulf Sulphur, 401 F.2d at 863.

${ }^{44}$ Texas Gulf Sulphur, 401 F.2d at 862 ("if corporate management demonstrates that it was diligent in ascertain that the information it published was the whole truth and that such diligently obtained information was disseminated in good faith, Rule $10 \mathrm{~b}-5$ would not have been violated.")

${ }^{45}$ Texas Gulf Sulphur, 401 F.2d at 863 ("The only remedy the Commissions seeks against the corporation is an injunction and therefore we do not find it necessary to decide whether just a lack of due diligence on the part of Texas Gulf Sulphur, absent a showing of bad faith, would subject the Corporation to any liability for damages."). 
The reservation of that question did not placate Friendly. In his initial memo on the case

he had argued for the fraudulent intent requirement from the common law, invoking the

authority of Jerome Frank, the SEC Chair prior to his appointment to the Second Circuit.

The ... more satisfactory[] escape is by holding that $\S 10(b)$ is limited to cases where there is some kind of an evil motive, as said by Judge Frank in Fischman v. Raytheon Mf. Co. 188 F.2d 783, 7862 Cir. 1951) - which I take to be required also under $\S 17$ of the 1933 Act. At the very least $\S 10-b$ doesn't authorize imposition for negligent execution in the course of pursuing a good motive. Certainly this would seem the appropriate view for private suits. One might argue that as a policy matter, a different view should prevail for injunction suits by the SEC. However, I see no basis in the statute for making that distinction and the SEC's power to stop trading will usually suffice to enable it to bring the company to terms. ${ }^{46}$

In his published concurrence, Friendly blurred the difference between scienter for injunctions and private actions for damages. Repeating his concerns about the frightening consequences for corporate liability in press release contexts such as this, Friendly somewhat obtusely, left some room for injunctions on a lower standard: "I am not disposed to hold that Congress meant to deny a power whose use in appropriate cases can be of such great public benefit and do so little harm to legitimate activity." But he paired this broader space for injunctions with a strong suggestion to the trial judge on remand that an injunction in a case such as this would not be appropriate ${ }^{47}$ Friendly's initial difficulty in drawing a line between private suits and SEC suits with respect to state of mind would prove dispositive when the issue eventually reached the Supreme Court, as we discuss below. ${ }^{48}$ For the time being, however, all options were available to the judges of the Second Circuit.

${ }^{46}$ Memo of HJF, SEC v. Texas Gulf Sulphur Co. (5/8/1968), Henry Friendly Collection, Box 135, Folder 5, Harvard Law School Library.

47401 F.2d at 869 ("Here there is no danger of repetetion....a once in a lifetime affair...I am content to leave it to [the trial judge] to consider whether although he has the power to issue an injunction, there is equity in this portion of the bill.")

${ }^{48}$ When the question of state of mind arose under Rule 14a-9, however, Friendly and the Second Circuit came down on the side of negligence. Gerstle v. Gamble Skogmo, Inc., 475 F.2d 1281 (2 ${ }^{\text {nd }}$ Cir. 
Other judges shared Friendly's concern about the negligence standard, but there was no

consensus among them on the correct standard. Irving Kaufman responded to Friendly's memo:

While I am attracted to HJF's proposal of limiting $\S 10(b)$ to cases where there is some kind of evil motive, or, in Loss' terms, p. 1766, imposing a watered-down scienter requirement, it seems to me that such an explicit formulation goes against the thrust of S.E.C. v. Capitol [sic] Gains ... Also, I see no reason why $\S 10(b)$ should not apply to a release issued with the best of motives that was truly distorted or prepared in a careless or wreckless [sic] manner. ${ }^{49}$

Capital Gains, which had offered strong support to the majority's broad insider trading holding, again loomed, this time as an obstacle to efforts to restrain corporate liability under Rule 10b-5. Judge Robert Anderson worried about the ability to courts to manage a disclosure regime so ambitious: "Aside from the dubious nature of the proposition that $\S 10(b)$ was intended to cover the field of corporate reporting, absent some more explicit guidance from Congress, the courts seem exceedingly ill-equipped to handle this new general supervisory task." ${ }^{50}$ He favored a recklessness standard set at a very high level:

A corporation should be held under $10 \mathrm{~b}-5$ for the consequences of a materially misleading press release only where the corporation's behavior in issuing the release is in some sense fraudulent or so reckless that evil intent would be presumed. While this would exclude negligence, it would cover reckless disregard for the accuracy of releases and for their effect on the market as well

1973). Friendly leaned heavily on the textual differences between $\S 10(b)$ and $\S 14(a)$, emphasizing the broader rulemaking authority afforded the SEC by the latter. Id. at 1299 . Friendly also looked to the structure of the Exchange Act:

while an open-ended reading of Rule $10 b-5$ would render the express civil liability provisions of the securities acts largely superfluous, and be inconsistent with the limitations Congress built into these sections, a reading of Rule $14 a-9$ as imposing liability without scienter in a case like the present is completely compatible with the statutory scheme.

Id.

${ }^{49}$ Memo of IRK, SEC v. Texas Gulf Sulphur Co. (5/14/1968), Henry Friendly Collection, Box 135, Folder 5, Harvard Law School Library.

${ }^{50}$ Memo of RPA, SEC v. Texas Gulf Sulphur Co. (5/27/1968), Henry Friendly Collection, Box 135, Folder 5, Harvard Law School Library. 
as cases of purposeful misrepresentation made in pursuit of an ulterior motive. ${ }^{51}$

Kaufman and Anderson eventually coalesced around a concurrence written by Friendly. ${ }^{52}$ The suggestion of a fourth member of the court with similar views, Wilfred Feinberg, that "the opinion should indicate our receptivity to some limiting doctrine in the private suit without spelling it out now" proved difficult to craft and Feinberg signed on to the majority opinion. ${ }^{53}$

\section{The Aftermath}

Texas Gulf Sulphur laid down a marker in 10b-5 jurisprudence, but it was hardly the last word. The "in connection with" element was the first issue from Texas Gulf Sulphur to reach the Supreme Court, just three years later. In 1971, purpose was still the coin of the realm in statutory interpretation of the securities laws. Justice William O. Douglas's opinion for the court in Bankers Life gave an even broader application to the phrase than Texas Gulf Sulphur had.

Thereafter the requirement receded in securities cases; the cases that did arise on this question, perhaps because the doctrine had been pushed to the edges of factual connection, led toward narrowing interpretations by both the Supreme Court and the Second Circuit. In contrast, scienter, which would not reach the Supreme Court until almost a decade later, became the key element policing the scope of corporate liability under Rule 10b-5.

\section{A. Bankers Life: Widening the reach of "in connection with"}

The facts of Bankers Life, a case that came to the Second Circuit and then to the Supreme Court in 1971, suggested egregious misconduct by those in control of the corporation.

${ }^{51}$ Memo of RPA, SEC v. Texas Gulf Sulphur Co. (5/27/1968), Henry Friendly Collection, Box 135, Folder 5, Harvard Law School Library.

52 Texas Gulf Sulphur, 401 F.2d at 864-868 (Friendly, J., concurring, joined in part by Kaufman and Anderson).

${ }^{53}$ Memo of WF, SEC v. Texas Gulf Sulphur Co. (5/28/1968), Henry Friendly Collection, Box 135, Folder 5, Harvard Law School Library. 
Moreover, there were clearly substantial losses to the shareholders. The connection between the securities transaction and the misconduct, however, was attenuated. The proceeds from an insurance company's sale of securities (bonds) in a market transaction at a fair price were then shuffled around by insiders with doubtful motives. The end result was that those proceeds were used to pay for the controlling shares. That is to say, the corporation's assets had been removed from the corporate treasury to pay the purchase price for the control block with no offsetting payment to the corporation. The panel decision, written by District Judge M. Joseph Blumenfeld sitting by designation and joined by Lumbard, found no Rule $10 \mathrm{~b}-5$ cause of action. ${ }^{54}$ The connection between the wrongdoing and the securities transaction was too remote. The facts looked like looting, not manipulation.

The Supreme Court granted certiorari. The decision, written for the Court by William O. Douglas, was handed down within three weeks of argument. ${ }^{55}$ The opinion was vintage Douglas, relying strongly on the purpose of the securities laws. The fraud smacked of mismanagement, as it was perpetrated by officers of the insurance company and their outside collaborators. Douglas found that fact "irrelevant" given the loss inflicted on the company as a result of the wrongful conduct. ${ }^{56}$ Also of no moment was the absence of fraud in the securities transaction itself. All that was necessary was that the injury to the company was "a result of deceptive practices touching its sale of securities." 57 The driving force behind the capacious "touching" standard was Douglas's extremely broad view of congressional purpose: "'disregard of trust relationships by

\footnotetext{
${ }^{54} 430$ F.2d 355 ( $2^{\text {nd }}$ Cir. 1971).

${ }^{55}$ Superintendent of Insurance v. Bankers Life and Casualty Co., 404 U.S. 6 (1971).

${ }^{56} / d$. at 10.

${ }^{57}$ Id. at 12-13.
} 
those whom the law should regard as fiduciaries are all a single seamless web' along with manipulation, investor ignorance, and the like." ${ }^{58}$

Bankers Life was the last hurrah of broad securities interpretations before the arrival of Lewis Powell and William Rehnquist at the turn of the year. Douglas's reasoning comes straight out of Capital Gains: "Section 10(b) must be read flexibly, not technically and restrictively." Douglas does not, however, cite Capital Gains for that rule of interpretation. ${ }^{59}$ Nor did he cite the Second Circuit's classic case, Birnbaum v. Newport Steel, ${ }^{60}$ limiting the reach of Rule $10 \mathrm{~b}-5$ as applied to corporate mismanagement. Douglas did, however, cherry-pick Birnbaum's holding, embracing its requirement that there be a purchase or sale of a security in a suit by a private plaintiff. ${ }^{61}$ (In this case the requisite transaction was the sale of bonds by the corporation.)

The effects of Douglas's virtual evisceration of the "in connection with" requirement would surface a generation later in cases which the language might have been a natural tool to confine corporate liability. In Stoneridge, for example, plaintiffs' complaint alleged that a massive accounting fraud by a television cable company (Charter) inflated the company's reported operating revenues and cash flow. ${ }^{62}$ The twist was that plaintiffs also named as defendants two equipment suppliers to Charter, Scientific-Atlanta and Motorola. The plaintiffs alleged that Charter paid the suppliers $\$ 20$ extra for each cable set-top box in return for the supplier's agreement to make additional payments back to Charter in the form of advertising fees. The suppliers had no direct role in preparing or disseminating the fraudulent accounting information, nor did they approve Charter's financial statements. ${ }^{63}$ Justice Anthony Kennedy,

\footnotetext{
58404 U.S. at 11.

59404 U.S. at 12.

60 Birnbaum v. Newport Steel, 193 F.2d 461 (2 ${ }^{\text {nd }}$ Cir. 1952).

${ }^{61}$ Bankers Life, 404 U.S. at 9.

62 Stoneridge Investment Partners, LLC v. Scientific-Atlantic, Inc., 552 U.S. 148 (2008).

63552 U.S. at 159.
} 
writing for the Court, focused on the lack of reliance: Investors relied on Charter for its financial statements, not the cable set-top box transactions underlying those financial statements. But Kennedy's principal concern was the specter of the seemingly unlimited reach of $10 \mathrm{~b}-5$ liability. Kennedy argued that the plaintiff's theory threatened to inject the $\S 10$ (b) cause of action into "the realm of ordinary business operations." ${ }^{14}$ According to Kennedy, "[w]ere this concept of reliance to be adopted, the implied cause of action would reach the whole marketplace in which the issuing company does business." ${ }^{65}$ Kennedy pointed to $\S 10(b)$ 's limit that the deceptive act must "be in connection with the purchase or sale of any security." And the limits that he was drawing around the concept of reliance could have more naturally been put into the "in connection with" element.

Why not use the "in connection with the purchase or sale of any security" language to limit the scope of the Rule $10 \mathrm{~b}-5$ cause of action? Reminiscent of the attitude articulated by Judge Kaufman in Texas Gulf Sulphur, the use of the "in connection with the purchase or sale" requirement would limit not only private plaintiffs, but potentially, the SEC, whose enforcement authority is limited by the reach of the statute. Kennedy acknowledged that the SEC'S enforcement authority might reach commercial transactions like those between Charter and its suppliers, but he was reluctant to afford the same freedom to the plaintiffs' bar. ${ }^{66}$ Given the need to cabin private rights of action, but maintain the SEC's discretion, the reliance requirement was a flexible tool. Reliance does not apply in enforcement actions brought by the

64552 U.S. at 161.

65552 U.S. at 160.

${ }^{66} 552$ U.S. at 161 ("Were the implied cause of action to be extended to the practices described here ... there would be a risk that the federal power would be used to invite litigation beyond the immediate sphere of securities litigation and in areas already governed by functioning and effective statelaw guarantees."). 
SEC, or criminal prosecutions brought by the Justice Department. ${ }^{67}$ Putting the limit on secondary party liability in the reliance element rather than "in connection with" allowed the Court to have its cake - unfettered government enforcement - and eat it, too - constrain the scope of private actions. Stoneridge shows that "In connection with" does no work in the Supreme Court's Rule 10b-5 jurisprudence. The Court's only contribution has been to reverse lower courts attempting to give the "in connection with" requirement some teeth. ${ }^{68}$

Fifteen years after Texas Gulf Sulphur and toward the end of his career, Friendly took another shot at "in connection with." Chemical Bank v. Arthur Anderson ${ }^{69}$ raised the issue of whether a pledge of stock was "in connection with the purchase or sale." Six weeks after argument that had produced an initial unanimous vote of the appellate panel to affirm the district court's holding that it was "in connection with," Friendly concluded that a pledge of stock was not a purchase or sale, maintaining the viability of the limits established in Birnbaum. Friendly persuaded one of his panel members, so his view became a majority. His opinion for the Second Circuit has been cited hundreds of times, not often finding "in connection with," but providing a way to explain this doctrine that others have found attractive. ${ }^{70}$

\section{B. State of Mind}

When the issue of state of mind in a private lawsuit eventually arrived at the Second Circuit five years after Texas Gulf Sulphur, a majority of the en banc Second Circuit (including Friendly) held "that proof of a willful or reckless disregard for the truth is necessary to establish

67 Geman v. SEC, 334 F.3d 1183, 1191 (10 ${ }^{\text {th }}$ Cir. 2003) ("The SEC is not required to prove reliance or injury in enforcement cases."); United States v. Haddy, 134 F.3d 542 (3d Cir. 1998) (government need not prove reliance in criminal case).

${ }^{68}$ SEC v. Zandford, 535 U.S. 813 (2002).

${ }^{69} 726$ F.2d 930 (1983)

70 Westlaw search of citing references for "720 F.2d 930" (March 13, 2018). 
liability under Rule $10 \mathrm{~b}-5$ for a private cause of action," ${ }^{71}$ distinguishing the holding in Texas Gulf Sulphur that had accepted a negligence standard for an injunction action. ${ }^{72}$ When the state of mind question reached the Supreme Court three years later in Ernst \& Ernst v. Hochfelder, ${ }^{73}$ the SEC supported the plaintiff in seeking a negligence standard under $\S 10(b)$. Powell's opinion for the Court rebuffed the SEC holding that negligence could not satisfy the necessary state of mind in a private cause of action. ${ }^{74}$ Powell relied heavily on a textual exegesis of $\S 10(\mathrm{~b})$ in his opinion; ${ }^{75}$ purpose received short shrift. The SEC's only consolation in Ernst \& Ernst was that Powell was forced, in order to hold his majority, to reserve the question of whether the scienter standard would apply to an action for injunctive relief brought by the SEC. ${ }^{76}$ Powell's conference notes from Ernst \& Ernst record Justice Stewart's view that an injunctive suit by the SEC might present a different case, ${ }^{77}$ but Powell's heavy reliance on the language of $\S 10(\mathrm{~b})$ in Ernst \& Ernst undermined that position when the issue came up in a subsequent term. Section 10(b) makes no distinction between government and private litigants, hardly a surprise given that Congress did not anticipate private litigation under $\S 10(b)$ when it adopted the Exchange Act in 1934.

${ }^{71}$ Lanza v. Drexel \& Co., 479 F.2d 1277, 1306 ( $2^{\text {nd }}$ Cir. 1973).

72 Lanza, 479 F.2d at 1305. Four judges would have permitted imposition of liability on a director for the corporation's misleading statements where the director failed to make any inquiry Lanza, $479 \mathrm{~F} .2 \mathrm{~d}$ at 1311 (Hays, J., dissenting in part, joined by Smith, Oakes, and Timbers). The misstatements occurred in an exchange of stock with the BarChris Construction Co. in a transaction at the same time as the famous $\S 11$ liability case under the Securities Act of 1933. The dissent would have held the outside director liable under Rule 10b-5 for conduct similar to the behavior giving rise for liability under $\S 11$ of the 1933 Act.

73425 U.S. 185 (1976).

7415 U.S.C. $\S 78$ (2000).

75425 U.S. at 197-201.

76 Telephone Interview by Pritchard with Greg Palm (former Powell clerk) (June 6, 2002); see Ernst \& Ernst v. Hochfelder, 425 U.S. 185, 193 n.12 (1976). The decision in Ernst \& Ernst was 6-2 with Justices Blackmun and Brennan dissenting and Justice Stevens not participating. If Powell lost Stewart and one more from Marshall, White, Burger and Rehnquist, the court would have split 4-4. At conference, Marshall suggested that he would be opposed to depriving the SEC of the negligence standard. Handwritten notes of Harry Blackmun from the Conference on Ernst \& Ernst v. Hochfelder, (Dec. 5, 1975), at 2, Harry Blackmun Papers, Library of Congress.

${ }^{77}$ Handwritten notes of Justice Lewis F. Powell, Jr., from the Conference on Ernst \& Ernst v. Hochfelder, (Dec. 5, 1975), at 1. 
Nonetheless, "policy concerns" raised by private litigation played an important role in Ernst \& Ernst, as they had in Texas Gulf Sulphur, this time leading to a more restrictive result.

Even with that necessary reservation, Powell did not go as far as he might have in laying out the requirements of Rule 10b-5. On the question of the required state of mind, Powell, objected to his clerk's distinction between "'knowing or intentional misconduct', on the one hand, and negligence or 'negligent misfeasance', on the other."78 Powell preferred the middle ground established by Judge Arlin Adams in a concurrence to a Third Circuit opinion:

Judge Adams in Korn [sic] (at p. 287) used language that I like:

"An intent to deceive, manipulate or defraud."

Adams, p. 285, also referred to Judge Friendly's formulation as including "recklessness" that amounts to fraud. What would you think of our using the term "scienter" and defining it early in the opinion, using the Adams/Friendly terminology? ${ }^{79}$

Friendly's influence was still being felt; this discussion suggests that Powell agreed with Friendly that recklessness would satisfy the scienter requirement. ${ }^{80}$ The first part of this suggestion was adopted, with the eventual opinion defining scienter as "a mental state embracing intent to deceive, manipulate, or defraud." 81 The final opinion, however, did not incorporate recklessness, specifically reserving the question. ${ }^{82}$ Powell, despite his desire to offer guidance to the bar, had a general preference for not addressing questions unnecessary to the decision.

78 Memorandum from Justice Lewis F. Powell, Jr., to Greg Palm, at 2 (Feb. 4, 1976).

79 Id. (citing Kohn v. American Metal Climax, Inc., 458 F.2d 255, 285, 287 (3d Cir. 1972) (Adams, J., concurring in part and dissenting in part) (quoting SEC v. Tex. Gulf Sulphur Co., 401 F.2d 833, 868 (2d Cir. 1968) (Friendly, J., concurring)).

80 Powell sent a copy of Ernst \& Ernst to Friendly, telling Judge Friendly that his "opinions and writing contributed significantly to our resolution of ... [the] case[]." Letter from Justice Lewis F. Powell, Jr., to Judge Henry J. Friendly 1 (Apr. 6, 1976). Judge Friendly responded that he "was delighted both at the result and at your skillful handling of the problems." Letter from Judge Henry J. Friendly to Justice Lewis F. Powell, Jr. 1 (Apr. 9, 1976).

${ }^{81}$ Ernst \& Ernst, 425 U.S. at 194 n.12.

82 Id. 
Accordingly, he left resolution of this issue to a subsequent case. ${ }^{83}$ Powell could have settled the law in Ernst \& Ernst, but held back.

The Supreme Court continued to avoided the question of whether recklessness satisfies $\S 10(b)$ even as each of the circuits offered different verbal formula. There were variations in these formulas, but they were all likely in a narrower range than decisions in the 1960s and 70s. Congress has been no better at resolving the question. The Private Securities Litigation Reform Act of 1995 contains a section entitled state of mind but eschews any description other than to say that the required state of mind (whatever it might be) must be pled with particularity. ${ }^{84}$ Powell can be forgiven for failing to anticipate that the Court would not resolve the issue; the Court's appetite for securities law cases would wane after he left the Court. Congress's failure to resolve the question is harder to justify. ${ }^{85}$

Four years after Ernst \& Ernst, the Supreme Court closed the door on the SEC's attempt to gain injunctive relief on the basis of negligence. ${ }^{86}$ In SEC V. Aaron, the Second Circuit (in an opinion written by Judge Timbers, former general counsel of the SEC) read Ernst \& Ernst v. Hochfelder narrowly in order to hold that the SEC only needed to show negligence when seeking an injunction. ${ }^{87}$ Friendly, who was not on the panel, expressed skepticism that Hochfelder could be limited in responding to a letter Timbers wrote him about the upcoming opinion: "An injunction cannot be issued unless there has been a violation, and if negligent misrepresentation is not a violation that would support a judgment for damages, how can it be a violation at all? ... I think the best way to mitigate the damage is to do what I did in Lipper and Commonwealth,

\footnotetext{
83 Telephone Interview with Greg Palm, supra note .

8415 U.S.C. 78u-4(b)(2).

85 Joseph A. Grundfest \& A.C. Pritchard, Statutes with Multiple Personality Disorders: The Value of Ambiguity in Statutory Design and Interpretation, 54 STAN. L. REV. 629 (2002).

${ }^{86} 446$ U.S. 680 (1980).

${ }^{87}$ Preliminary Memorandum, Aaron v. SEC, to Justice Lewis F. Powell, Jr. 1 (Oct. 12, 1979).
} 
namely, to read Hochfelder as applying only to negligent misrepresentation." ${ }^{88}$ Powell worried about the SEC as well as private litigants: "[A] suit [by the SEC] [and] an injunction are punitive [and] can impose severe stigma [and] other penalties." ${ }^{89}$ Friendly's concern in Texas Gulf Sulphur that§ 10(b) would not easily support a distinction for the required state of mind between private actors (recklessness) and government actors (negligence) turned out to be prescient. Aaron raised another issue that was not present in Ernst \& Ernst: the state of mind required for liability under $\S 17(a)$ of the Securities Act, which prohibited "any transaction, practice, or course of business which operates or would operate as a fraud or deceit upon the purchaser." ${ }^{90}$ The Court previously had found-in Capital Gains-that similar language in the Investment Advisers Act did not require the SEC to establish an intent to deceive. ${ }^{91}$ Powell discussed the case with Justice Stewart before the conference and they agreed upon a resolution. Powell apparently came round to Justice Stewart's view that $\S 17(a)$ could not be interpreted in the same fashion as $\S 10(b) .{ }^{92}$ Text prevailed over policy. Justice Stewart wrote the opinion for the Court, leaning "heavily + properly on Ernst \& Ernst.." ${ }^{93}$

${ }^{88}$ Note HJF to Judge Timbers, SEC v. Commonwealth Chemical Securities, Inc. (3/22/1978), Henry Friendly Collection, Box 89, Folder 5, Harvard Law School Library. Here Friendly expressed agreement with Blackmun in Hochfelder who had preferred the same standard for injunctions and private damages, but then opted for the lower standard for each as opposed to the higher standard for each that the Court majority got to after Aaron.

${ }^{89}$ Bench Memorandum, Aaron v. SEC, to Justice Lewis F. Powell, Jr. 1 (Feb. 15, 1980) (emphasis added by Justice Lewis F. Powell, Jr.).

${ }^{90}$ Aaron v. SEC, 446 U.S. 680, 687 (1980) (quoting 15 U.S.C. $\S 77 q(a)(3)$ ).

${ }^{91}$ Capital Gains, 375 U.S. at 195 (construing section 206 of the Investment Advisers Act, Pub. L. No. 76-768, 54 Stat. 789, 852 (1940), which makes it illegal for any investment adviser "(1) to employ any device, scheme, or artifice to defraud any client or prospective client; (2) to engage in any transaction, practice, or course of business which operates as a fraud or deceit upon any client or prospective client").

92 Handwritten notes of Justice Lewis F. Powell, Jr., from the Conference on Aaron v. SEC (Feb. 27, 1980), at 1. Powell notes on his copy of Justice Stewart's eventual draft that Justice Stewart "reads $\S$ 17(a)(3) differently from my tentative view - but P.S. persuades me." Justice Potter Stewart, First Draft Opinion, Aaron v. SEC 1 (circulated Apr. 16, 1980) (handwritten notes of Justice Lewis F. Powell, Jr.).

93 Justice Potter Stewart, First Draft Opinion, Aaron v. SEC, supra note 87, at 1 (handwritten notes of Justice Lewis F. Powell, Jr.). Justice Stewart again reserved the question of whether the definition of scienter included reckless behavior. Aaron, 446 U.S. at 686 n.5. 
For the SEC, Aaron was a victory, despite the Court's rejection of its argument for a negligence standard under $\S 10$ (b). Statutory language and precedent preserved the enforcement tool of $\S 17(a)$, despite the misgivings of at least Powell and Stewart about the SEC's use of injunctions. The threat perceived by Powell was confined; Stewart took care to note that the Court did not address whether a private cause of action exists under $\S 17(a) .{ }^{94}$

\section{Conclusion}

Texas Gulf Sulphur, a critical case in the development of insider trading, had an equally significant impact on the development of corporate liability under Rule $10 \mathrm{~b}-5$ for misstatements by corporate officers even in the absence of trading by either the corporation or its officers. This aspect of the opinion is interpretive twin of the insider trading holding-the emphasis is on the broad purposive approach endorsed by the Supreme Court in Capital Gains and J.I. Case v.

Borak. Texas Gulf Sulphur is truly a product of the jurisprudence of the 1960s.

On the other hand, the Second Circuit's decision on corporate liability differs from its insider trading holding in that it also contained the seeds of limits, particularly scienter, that would be adopted by the Supreme Court in the 1970s. The Supreme Court broadened the "in connection with" requirement in Bankers Life. State of mind, however, took a different path. Powell insisted on a scienter requirement for private causes of action, influenced by the views of Henry Friendly. Unlike the Second Circuit, however, Powell ultimately persuaded his colleagues to adopt the scienter standard in SEC enforcement actions as well. Nonetheless, the framework for corporate liability established by Texas Gulf Sulphur, despite having been pruned back a bit by the Supreme Court and Congress, is still reflected in the litigation weapon against corporations that Rule $10 \mathrm{~b}-5$ is today.

\footnotetext{
94 Id. at 689.
} 